\title{
EDITORIAL
}

\section{Programa de Assistência Técnica da ONU para 1956}

Da. "Public Administration Clearing House", de Chicago, chega-nos às mãos interessante e alvissareira noticia sôbre a expansão que pretende dar, no próximo ano, ao seu programa, o comitê de assistência técnica do Conselho Econômico e Social da ONU. No setor de administração pública estão incluídos mais de 30 Estados e Territórios, num raio de ação jamais atingido nestes cinco anos de expansão daquele programa.

É notável o aumento de propostas de assistência técnica em administração pública para 1956, pois é esta a primeira vez que o programa anual é baseado na programação por país. Até agora, a distribuição de fundos entre as agências especializadas das Nações Unidas - UNESCO, Organização Mundial de Saúde, Organização Internacional do Trabalho. Organização de Alimentação e Agricultura, Organização Internacional de Aviação Civil - subordinava-se a complicadas fórmulas. As propostas eram discutidas isoladamente por essas agências com o ministério interessado do país solicitante, havendo, assim, pouca possibilidade para um exame mais aprofundado e uma visão de conjunto mais completa das verdadeiras necessidades. De agora em diante, será o govêrno do país beneficiado que terá a última palavra na determinação dos tipos de ajuda técnica de que mais necessitar. 
Entre as técnicas de administração geral incluidas no programa, convém notar a do planejamento, para a qual o Brasil apreșentou solicitação específica, no tocante ao desenvolvimento.

Um dos principais resultados da programação por país será o aumento de pedidos de técnicos especialistas a serem designados para diferentes missões; bem como de bôlsa de estudo fora do pais, concedidas aos nacionais. O instituto ou seminário de treinamento - importante instrumento da assistência técnica - raramente poderá ser usado econômicamente num só país, a não ser nos maiores. De um modo geral, êsses institutos ou seminários serão organizados por grupos de países com problemas comuns. Uma pequena percentagem do Fundo de Expansão é reservada a projetos regionais, alguns dos quais, de grande significação no setor da administração. Entre as iniciativas dignas de nota neste particular, estão a Escola de Administração Pública da América Central, o Instituto de Administração Pública para a Turquia e o Oriente Médio e, finalmente, a Escola Brasileira de Administração Pública, órgão da Fundação Getúlio Vargas, que, em cinco anos de funcionamento, já formou 26 bacharéis em Administração Pública, 55 técnicos de Administração e proporcionou treinamento a 1.027 altos funcionários, federais, estaduais e municipais, inclusive a funcionários latinos-americanos que nela aperfeiçoaram os seus conhecimentos técnicos.

Como se vê, são das mais promissoras, no próximo ano, as perspectivas da assistência técnica por parte das Nações Unidas . 